\title{
EQUiLIBRIUM
}

Quarterly Journal of Economics and Economic Policy

2015 VOLUME 10 ISSUE 1, March

p-ISSN 1689-765X, e-ISSN 2353-3293

www.economic-policy.pl

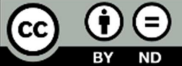

Siddiqui, K. (2015). Economic Policy - State versus Market Controversy. Equilibrium. Quarterly Journal of Economics and Economic Policy, 10(1), pp. 9-32, DOI: http://dx.doi.org/10.12775/ EQUIL.2015.001

Kalim Siddiqui*

University of Huddersfield, United Kingdom

\section{Economic Policy - State Versus Market Controversy}

\section{JEL Classification: $H 11$}

Keywords: economic policy; 'market-centric' model; role of the state; economic governance

\begin{abstract}
There was a wide ranging debate in the 1950s and 1960s in the developing countries about the role of the state in their economy when these countries attained independence, with developing their economies and eradicating poverty and backwardness being seen as their key priority. In the post-World War II period, the all-pervasive 'laissez-faire' model of development was rejected, because during the pre-war period such policies had failed to resolve the economic crisis. Therefore, Keynesian interventionist economic policies were adopted in most of those countries.

This is a theoretical paper, which is based on a review of published papers in the field of economic policies, especially about the debate on the role of the state and market. In this study, a wide range of data sources are presented, which includes statistics generated by a number of organisations that are not agencies of a particular government. This is useful since data are compiled by a wide range of organisation such as IMF, World Bank and WTO. Secondary data would help our study to answer the research questions. There seems to be greater potential for examining statistical data produced by various organisations that are relatively independent of the national government.
\end{abstract}

(C) Copyright Institute of Economic Research \& Polish Economic Society Branch in Toruń Date of submission: November 16, 2014; date of acceptance: January 5, 2015

* Contact: k.u.siddiqui@hud.ac.uk, University of Huddersfield, Queensgate HD1 3DG, United Kingdom 
The study finds that more than two decades of pursuing neoliberal policies has reduced the progressive aspects of the state sector. The on-going crisis in terms of high unemployment, poverty and inequality provides an opportunity to critically reflect on past performance and on the desirability of reviving the role of the state sector in a way that will contribute to human development.

\section{Introduction}

This paper examines the role of the state and the market in the economic policy in developing countries. Following World War II, the all-pervasive 'laissez-faire' model of development was rejected, because during the prewar period such policies had failed to resolve the economic crisis. Therefore, Keynesian interventionist economic policies were adopted, and North America and the western European countries witnessed a long, uninterrupted phase of growth, often referred to as the 'Golden Period' of capitalism. State intervention was seen as the only possibility to avoid the market failures of the past.

During the 1970s and 1980s, as the economic crisis began to bite hard in the US and the UK, neoclassical economists gained new respectability. They advocated a greater role for the market by reducing the state's role in the areas such as the labour market, supporting privatisation of state enterprises, and the removal of price and interest rate controls (Harcourt, 2014; Little, 1982).

More than two decades of pursuing these neoliberal policies has reduced the progressive aspects of the state sector. The on-going crisis in terms of high unemployment, poverty and inequality provides an opportunity to critically reflect on the past performance and to consider the desirability of reviving the role of the state sector in a way that would help contribute to human development.

This study will briefly examine the industrial policies previously adopted by developed countries in addition to their more recent experiences of state intervention. This issue merits discussion because the role which the state plays in setting economic policies impacts on the levels of employment, income, education, the standard of living and, most importantly, national sovereignty. The major financial crisis of 2008 has generated conditions which prompt a reassessment and consideration of alternatives to the status quo.

Throughout the years of the Great Depression, a debate continued between Keynes and Hayek. During the post-war period of reconstruction, the Keynesian model was adopted by western governments, but with the arrival of the economic crisis in the 1970s, neoclassical economists gained new 
importance and their recommendations were adopted by the US and the UK governments as an alternative way out of the crisis.

Neoclassical or neoliberal economists such as Friedman, Hayek, Krueger, and Little, strongly opposed state intervention, on the grounds that the state was not an impartial agent, but led by politicians and bureaucrats who faced constant pressure from interest groups. This led to the introduction of various forms of regulatory laws, which ultimately resulted in increased corruption, red tape, and rent seeking (Little, 1982; Hirschman, 1982; Krueger, 1974).

By focusing on corruption, favouritism and other forms of self-seeking behaviour, the neoliberal economists highlighted how a government with 'good intentions' was, in reality, controlled by special interest groups. Therefore, they advocated a minimal role for the state, arguing instead that it should be left to price mechanisms in the competitive market to decide what should be produced and in what quantities. Their model completely shifted the focus from 'getting the policies right' to an overriding concern with 'getting the price right'. The IMF and the World Bank accepted their recommendations and imposed 'Structural Adjustment Programmes' on developing countries to increase the role of the market, putting pressure on governments which were seeking loans to adopt these policies (Siddiqui, 1994a).

In the past, governments intervened in business affairs, frequently correcting market failures, which is now seen by neoliberals as futile and even wasteful behaviour. Therefore, a critical approach is required to understand the role of the state in the economy in the $21^{\text {st }}$ century, which draws on the past experiences of both the developed and developing countries. Lessons may be learnt from this, which could be of specific benefit to developing countries, enabling them to build manufacturing sectors that could, in turn, ultimately help to reduce unemployment and poverty, and also address environmental issues.

This paper is organised as follows: The opening section provides the background to this topic, outlining the key issues to be addressed and their importance in the $21^{\text {st }}$ century. This is followed by an overview of the 'market-centric' model and an examination of the past experiences relating to industrial policies in the developed countries. The focus then shifts to the issue of state intervention and industrial policies in the developing countries and the East Asian countries, highlighting some key aspects of this continuing debate. The study concludes by making the case for a reconsideration of the role of the state in the economic affairs of the developing countries. 
The methodology to be followed here is derived from the aims of the study. This engages an understanding of the issues in the research project. The research question requires international comparisons of statistics and provides the main source to answer the research questions and address the objectives of this paper. Analysing the secondary data which has already been presented is the only possible way to get macroeconomic data. The secondary data sets together provide quantifiable information and statistics published by the governments for their country. Country based multiple source data sets are also available from governments' publication and international organisations. These include data such as IMF, World Bank, OECD and UNCTAD statistical data collected for member countries.

Analysing existing secondary data offers the prospects of being able to explore research questions of interest to our study without having to go through the process of collecting. It also offers the opportunity of being able to employ high quality data sets that are based on large macroeconomic data.

\section{'Market-Centric' Economic Theory}

Following the economic crisis in the early 1980s in North America and Europe, the 'market-centric' paradigm re-emerged as a viable alternative to neoclassical economic theory. Let us briefly examine its key elements. Neoclassical economic theory emphasises that the market is an ahistorical phenomenon which functions as some sort of universally applicable mechanism for the efficient allocation of resources. Neoliberals visualise the market as socially 'neutral', and human beings as selfish (Little, 1982). They reject any limits to the free market and insist that voluntary actions in the market sphere are inevitably harmonic, peaceful and mutually beneficial to the whole society (Hirschman, 1982; Krueger, 1974). However, market failures can be witnessed in the areas such as education, the environment and pollution.

State regulation can be widely seen in the setting of taxes and tariffs and in the regulation of the macroeconomic dynamics of the system of finance and credit. Regarding the role of the state in economic affairs, Thomas Friedman argues: "The hidden hand of the market will never work without a hidden fist - McDonalds' cannot flourish without McDonnell Douglas, the builder of F15. And the hidden fist that keeps the world safe for Silicon Valley's technologies is called the US Army, Air Force, Navy and Marine Corps" (Friedman, 1999, p. 373). 
The neoliberals insist that the state and public sectors are inefficient and only markets and the private sector are capable of creating growth, employment and human welfare. But in reality, for the last three decades, neoliberal policies have resulted in largely benefitting financial capital, monopolies, and the very rich. Working people and the rest of the society witnessed a rise in joblessness, poverty, stagnation or a decline in wages, and cuts in welfare payments. Austerity has added to the misery of the majority by shrinking the public services on which people depend.

By focusing exclusively on the market, which is said to epitomise freedom and equality without also concentrating on the social relations inside the production system, renders the effect of the market system and the broader economy invisible. The idea of the market economy was a set of policies intended to force people to accept market discipline, meaning they had to adjust their economic and political life to the dictates of the market (Perelman, 2011). Neoliberal ideas have become instruments for explaining, legitimising and controlling workers within the market system.

Neoclassical economists assume that in the beginning there was the market' (Williamson, 2003). The model also assumes that markets are perfectly competitive. The market is seen as something which has naturally existed from the very beginning of human civilisation. They argue that the state, on the other hand, should be seen as man-made, an idea which emerged as society itself evolved. Contrary to their beliefs, however, economic historians have found there were no markets in the beginning, except those which operated at a very local level to supply the most basic necessities; markets were not important nor did they play a key role within ancient communities.

The neoliberal model does not take into account the social relations of production and disregards the well-being of workers. It is the marriage of macroeconomics with the individualistic-driven market economy. The market is being used to create a fear of losing employment, reducing wages to further power the corporations. The emphasis on efficiency at micro level and on market-based explanation is unable to explain the structural inefficiency which leads to the enormous waste of resources (Perelman, 2011).

Today's developed countries pioneered and relied on state interventionist policies for their industries and trade during the early stages of their industrialisation. Moreover, well-designed interventionist policies in the developing countries have not only been impressive with regard to their performance but overall have fared better in relative terms with their developed counterparts at comparable stages in their development. This is not to claim that state intervention always works. If we consider, for example, the 
most recent experiences of the industrial policies followed by East Asian countries, these were based on interventionist policies, except in the case of Hong Kong, previously a British colony. Dramatic growth rates were formulated and applied with the state actively promoting industrialisation in the early 1950s (Wade, 2004).

Neoclassical theory rests on the mistaken premise that markets and politics are always autonomous; they are not autonomous, as neoliberals claim, but are linked and mutually dependent. The growth of private enterprise does not take place in a vacuum. It requires government support for an environment conducive to price mechanisms and the appropriation of surplus and investment to develop.

Bhagwati (1982) argues that, irrespective of the possible genuine intentions on the part of the government, interference with the economic functioning of private enterprises can create incentives for rent-seeking behaviour. Even when there are market failures, this can make things worse by shifting resources from productive to unproductive activities. On the question of market failure, Chang argues that, "the same market could be seen as failing by some while others regard it as normally functioning, depending on their respective theories of the market [...] Many people think that one of the biggest 'failures' of the market is its tendency to generate an unacceptable level of income inequality" (Chang, 2002, p. 544).

Ian Little (1982), another neoclassical theorist, has argued that a microeconomic approach, which relies on profit and growth maximisation at firm level, will be able to outperform and be more efficient than state intervention, because the latter will be based on wholly insufficient information. Like other neoclassical economists, Little(1982) has stressed there is bound to be a significant discrepancy between the intended official policies and their implementation due to the self-seeking of the bureaucracy (Hirschman, 1982).

A non-competitive market is seen as a failing market by the neoclassical economists, but others, such as Schumpeter, accept that the existence of a non-competitive market is an inevitable feature of a successful capitalism (Goldsmith, 1995). The issue of perfect information is seen as necessary for a competitive market to exist and may lead to the diffusion of new technology, which may, in turn, mean no incentives for entrepreneurs to innovate with new technologies. Certain environmental regulations and minimum wages have often been criticised as interference in business freedom and adding to business costs but nowadays regulations concerning factory pollution standards and safety in the work place are hardly seen as intrusive policies. 
The outcomes of neoliberal policies in terms of socio-economic variables indicate that in the US and the UK the benefits of such growth have disproportionately gone to the top income groups. For instance, since the adoption of neoliberal policies, both these countries have witnessed growing disparities in income and wealth, and this rise has been accompanied by shifts in wealth from wages to capital, cheaper imports and the relocation of some manufacturing industries to cheaper cost countries, squeezing wages further and curtailing the power of unions in the Western countries. Neoliberal policies have created wealthy financial centres in big cities such as New York and London, while the traditional manufacturing areas have suffered from low investment and high unemployment (Wade, 2009; Stiglitz, 2006).

\section{State, Free Market and Economic Governance}

It is useful here to briefly trace the links between state, market and economic governance in the past. The state's role in providing guidance and playing a leading role in economic policies in Britain and the US, for example, was originally very different from how it is currently portrayed. When developed countries such as Britain and the US were laying the foundations for the modern manufacturing sector, the state was very active in promoting and protecting domestic business interests against those of foreign companies. In fact, in the early phase of their industrialisation, most of today's developed countries adopted industrial policies which were very proactive, and certainly not 'open door' policies of the type now recommended to developing countries. For example, Britain had protectionist policies in place when it was trying to catch up with Holland, which had more advanced industries than Britain (Chang, 2007).

For example, the Corn Laws in Britain, which had protected farmers since the $13^{\text {th }}$ century, were finally repealed in 1846 . Over the next two decades, most of the import tariffs were removed (Polanyi, 1957). There is also evidence that the British government intervened in establishing industries: "During the early phase of Britain's industrial development, Robert Walpole, the British Prime Minister in 1721, launched an economic policy to transform the country from an exporter of raw material into an industrially developed nation. He sponsored legislation directed towards protecting domestic industry from foreign competition and export companies, supported through export subsidies. Moreover, import tariffs were raised on foreign goods, while import tariffs on raw materials were removed to make 
imports cheaper for the country's export industry. Walpole's policies were not those of a "free market". Instead, his government provided heavy protection and subsidies to infant industries" (Girdner \& Siddiqui, 2008, p. 9). Only after the Industrial Revolution was well established did the government open up domestic markets to foreign completion.

The British Crown granted monopoly status to their companies and also made treaties with foreign governments to obtain exclusive trading privileges for them (Polanyi, 1957). At the same time, the government put up import taxes and paid subsidies to domestic manufacturers: "The [British] East India Company and other companies chartered by the monarchy opened markets around the world to British goods. Other grants of monopolies were designed to encourage new industries from abroad to start up in Britain. For instance, the Navigation Acts, once calling them 'perhaps, the wisest of all commercial regulations of England' because they promoted national defence' $[\ldots]$ The net effect of British mercantilism was to nurture companies that, when The Wealth of Nations appeared, were strong enough to exploit new markets and new technology, making England the workshop of the world" (Goldsmith, 1995, p. 645).

Thus, the state initially played a defining role in Britain in the development of the market economy, rather than this having naturally existed as assumed by the neoclassical theorists. As Polanyi has argued, "The road to the free market was opened and kept open by an enormous increase in continuous, centrally organised and controlled interventionism. To make Adam Smith's 'simple and natural liberty' compatible with the needs of a human society was a most complicated affair. Witness the complexity of the provisions in the innumerable enclosure laws; the amount of bureaucratic control involved in the administration of the New Poor Laws which for the first time since Queen Elizabeth I's reign were effectively supervised by the central authority [...] new powers, organs, and instruments required for the establishment of laissez-faire (Polanyi, 1957, p. 140)

In the US, too, state intervention was seen at the time as the best available policy tool to establish property rights, facilitating the provision of infrastructure such as the railroads, and even the success of early industrialisation. Right up until the beginning of World War II, the US had a heavily protected economy. For example, it had by far the highest tariff rates among the Western countries for most of the $19^{\text {th }}$ century, when its average tariffs rates were approximately $40 \%$, while those of Austria, Belgium, France and Sweden were no more than $20 \%$ during the same period.

The first Secretary of the US Treasury, Alexander Hamilton (1789-95), set out a clear strategy concerning how the country should develop an industrial base in his Reports of the Secretary of the Treasury on the subject 
of manufactures (Chang, 2007). It is well-documented that in the past the state was clearly involved in creating the conditions for industrial development(Girdner and Siddiqui, 2008). It is well known that infrastructure plays a crucial role in economic development and, therefore, the government should take a lead in making investments in infrastructure. For example, the US government took the responsibility for investing heavily in infrastructure such as railroads and telegraph lines, due to their high costs and long gestation periods. During the latter half of the $19^{\text {th }}$ century, millions of acres of land were made available by the government for these tasks. Education was another area which was seen as too important to be left to private initiative alone. For instance, schooling was made mandatory for the first time in 1852 by the state of Massachusetts. Soon other states followed, because it was considered that businesses often chose to invest too little money in their employees' skill development; it was also feared that if workers could leave any time, they would ask for higher wages to stay (Polanyi, 1957).

The National Banking Act of 1863 was the first US bank regulation to provide a stable financial system and currency, which assisted the business sector (Polanyi, 1957). The state also took the lead in investing in the education sector to improve the general skill level within the country. The US government involvement in agricultural R\&D began in Connecticut in 1875, where the government funded research into hybrid corn; a further breakthrough came from a government-funded research laboratory in 1917 with new seeds producing a higher yield. This was soon spread to other states; the government also provided financial incentives to farmers (Chang, 2007; Polanyi, 1957).

Similar state intervention policies were part of the official policies in $19^{\text {th }}$-century Germany, too. In the 1840 s, a German academic, Friedrich List, argued that his country firstly needed to build a successful manufacturing sector and only then would it be able to follow 'free trade' policies. He concluded that "in order to allow freedom of trade to operate naturally, the less advanced nation [Germany] must first be raised by artificial measures to that stage of cultivation to which the English nation has been artificially elevated" (List, 1966, p. 131). Similarly, Japan later followed state intervention policies to strengthen its industrial base against foreign competition. As Cowling and Tomlinson's (2011) study concludes: "The Japanese case also demonstrates that, with a degree of protectionism, industrial strategy and state investment can deliver dynamic growth for a (significant) period. However, in the long term, Japan (and Russia) also highlight that where a corporatist policy is pursued and hierarchical governance structures emerge, then long term development paths are likely to be de- 
termined by the few with the public interest being compromised" (Cowling and Tomlinson, 2011, p. 843).In short, in almost all present day developed countries state intervention was seen as the best-option policy to establish the manufacturing sector and it played a key role in their economic development and sectoral transformation.

\section{The Role of State in the Developed Countries}

The passion for the 'free market' has emerged from various sources, beginning with Adam Smith's ideological premise that by means of market forces each individual's free and selfish pursuit of gain will be transformed as if by an invisible hand to achieve socially optimal results. It is worth revisiting Adam Smith's ideas, since they are so often quoted by neoclassical economists to support their laissez-faire policies. Other economic theorists, such as Amartya Sen (1999), strongly support the role of the state, especially in the areas of social responsibility including health care, education and other welfare measures, and the maintenance of adequate levels of employment. Sen attempts to combine Adam Smith's economic ideas with moral philosophy (Smith, 1976), noting, for instance, that Smith acknowledges that the government has an important role to play, namely, "the duty of erecting and maintaining certain public works and certain public institutions" (Smith, 1937, p. 651). These public goods include provisions to accumulate and encourage the development of technology and education, both of which can be expected to contribute positively towards raising the productivity and wellbeing of society.

It is argued that the private sector does not have the necessary resources to provide sufficient social capital by itself. As Adam Smith points out, these tend to be assets "which it can never be for the interest of any individual, or small number of individuals, to erect and maintain; because the profit could never repay the expense to any individual or small number of individuals, though it may frequently do much more than repay it to a great society" (Smith, 1937, p. 862). He argues that Law and Order, property rights and the re-enforcement of contracts prepares the ground for market exchange to take place. He suggests that the government can act as a referee in various contract disputes, which could be prerequisites for marketbased resource allocation (Goldsmith, 1995).

The assumption is that the state should serve as a rational actor for the benefit of the society as a whole i.e. in the interests of the common good. Broadly speaking, the main arguments in favour of state intervention seem 
to centre on five areas: 1) the re-enforcement of property rights, contracts and procurement of institutions for production and exchange; 2) macroeconomic policies; 3) procurement of infrastructure and provision of public services, such as health and education, 4) operational control over private companies, and 5) participation in the production of goods and provision of services.

State intervention in economic policies was adopted by Britain, the US and Germany during the $19^{\text {th }}$ century. Whilst in Britain and the US, the state remained in the background but continued to play a crucial role, in Germany the state's role in policy initiatives to build the domestic manufacturing sector was very visible and it successfully managed to transform the economy during that period. Later, in the 1950s in Korea and Taiwan, the state played a crucial role in the issues including land distribution, construction of infrastructure, and industrialisation whilst during in the 1980s in China, the 'revolution from above' state played a more active role in supporting domestic industrialisation (Chang, 2007; Wade, 2004; Amsden, 1989).

Rather than prematurely opening their industries to foreign competition, other western European countries followed Britain's lead as soon as their industries were strong enough to compete. However, the neoclassical economists choose to ignore these historical facts, and deny governments a role in formulating industrial policy in the developing countries.

In recent years, there has been growing dissatisfaction with the neoliberal paradigm (i.e. free-market) that has dominated economic policy over the last few decades. In fact, in the early 1980s, the so-called 'Washington Consensus' emerged which included the promotion of policies such as the free-market economy, de-regulation, privatisation, and trade and capital liberalisation. These were widely backed by international financial institutions, including the World Bank and the IMF, and the British and US governments (Williamson, 2003; Siddiqui, 1994a). Such policies have increased corporate power and this dominance of the corporate sector and the economic crisis that have followed have led many to question the relevance of such policies and seek alternative policies for the $21^{\text {st }}$ century (Narcis \& Stiglitz, 2009; Fine et al., 2003).

According to Mohanty and Miraglia (2012), although neoliberalism "inevitably places capitalist interests above the needs and hopes of the people, it is the people's movements (anti-colonial/anti-imperial, peasant, ecological, labour...) that have exposed the faults-line of neoliberal capitalism and placed questions of democracy, equity and justice at the centre of the struggle for emancipation" (quoted in Harcourt, 2014, p. 1308). 
There is an on-going debate concerning the role of the state in economic policy measures between those who favour state intervention in designing economic policy and the neoliberals, who will not countenance any economic intervention by the state. Some of these issues involve the design and implementation of public policies aimed at improving the economic well-being of citizens by fostering economic development and preventing crises. The interventionist argument has its origins in the early period of capitalism in Britain, when some defended protectionist policies and monopoly concessions granted by the government in the $16^{\text {th }}$ and $17^{\text {th }}$ century. Later, however, in the $18^{\text {th }}$ century, the continuation of such policies was opposed by Adam Smith who favoured free trade and laissez-faire capitalism. However, in the $19^{\text {th }}$ century, with the exception of the UK, all the major European countries and the US followed protectionist policies, employing active state intervention to protect their domestic industries against foreign competition (Chang, 2002).

Any comparative analysis of economic performance requires an analysis of a longer period of data. For example, between 1945 and 1980, the western European economies recorded higher growth rates than the US. A closer examination of the state role in the US economy since the mid-1990s provides some interesting facts. During that period, despite assigning a major market role to the crucial sectors of the economy, the state continued to play a leading role in both the decimation and the development of research and innovation, often through state-controlled defence industries (Kitson, 2005). Cowling and Tomlinson (2011, p. 847) conclude that "wider public interests are likely to be better served through an inclusive approach where governance structures are relatively diffuse and allow opportunities for all stakeholders to participate in the development process".

In the developed economies state ownership can be vast. For instance, in the much celebrated free enterprise of Singapore, the land is fully owned by the state and also about $85 \%$ of the housing is provided by the state. Also more than $20 \%$ of the Gross National Product (GNP) is produced by the state owned enterprises in Singapore (Siddiqui, 2010b), whilst in the UK, the public sector National Health Service is still the largest employer. The state plays an important role in most countries by providing backing for the monetary and credit system. Certain public goods such as street lighting should be provided from public expenditure. The procurement of infrastructure and the provision of public services are based on the notion that these are the necessary preconditions for economic growth and social progress. The private sector would be unable to produce by itself. For the proper functioning of contemporary economies, it is widely acknowledged that areas such as mediation, contract and regulation can assist the market. 


\section{Role of the State in the Developing Countries}

The neoclassical model of economic development suggests the primacy of the market as a means of improving the standard of living and income in the developing countries (Little, 1982). Top economic experts and financial officials from all the Latin American countries, except Brazil, were trained in the neoclassical tradition in the US in the 1980s and were assigned to oversee the implementation of the IMF's prescriptions after the debt crisis. These countries mostly focused on macroeconomic stabilisation programmes including privatisation of state enterprises, trade liberalisation and restricting the role of the state in the economy (Siddiqui, 1994b). These governments had no inclination to learn from the East Asian experiences of the recent past. They saw the state as the source of all 'distortions' and associated this with the failure of their own previous 'import substitution' policy (Amsden, 2009a).

Neoliberal economists say that the invisible hands of the market are the best allocating forces to bring about rapid growth. Economic developments are regarded as best driven by private enterprises with little or no state intervention (World Bank, 1993; Little, 1982). Latin America's 'import substitution' policies were blamed for producing inefficient, rent-seeking behaviour, slow growth and macroeconomic imbalances. Another proponent of neoliberalism, Deepak Lal (1983), is highly sceptical about the role of the state in the government of developing countries. According to him, "many developing countries are closer in their official workings to the rapacious and inefficient nation-state of $17^{\text {th }}$ - or $18^{\text {th }}$-century Europe, governed as much for the personal aggrandizement of their rulers as for the welfare of the rule" (quoted in Wade, 2004, p. 10).

Latin American governments began to embark on interventionist policies in the 1930s, their aim being to encourage and lay the foundations for domestic industrial development. By encouraging a policy of 'import substitution', domestic producers would develop the capacity to produce goods that would otherwise be imported. High tariff rates discouraged imports, while subsidies and local demands encouraged domestic producers. This policy was rooted in populist movements led by individuals such as Perón in Argentina, Cárdenas in Mexico, and Vargas in Brazil. This strategy was initially successful in developing an industrial base in countries such as Argentina, Mexico and Brazil, but in the 1970s, such policies began to experience crisis (Shapiro \& Moreno-Brid, 2014). 
Moreover, these countries generally relied on imports of new machinery and technology and also capital investment by multinational companies (MNCs). In Brazil, NMCs accounted for 44\% of all domestic sales in 1965, while domestic private and public companies together accounted for the remaining 56\%. By 1972, MNCs controlled more than half of the total manufacturing investment in both Brazil and Mexico. By the mid-1970s, this model had entered deep crisis with public sector management and the growth of vast bureaucracies encouraging corruption. By the late 1970s, these countries faced chronic financial difficulties, particularly with balance of payments deficits.

Since Latin America's exports consist of naturally based products, these sectors have limited potential for productivity growth and technological upgrading. In 2012, just ten commodities and mineral products including coffee, soya beans, sugar, fruit, iron ore, copper, gas and oil, accounted for more than 40\% of Latin America's total exports: "In Mexico, Latin America's alleged success story in reorienting domestic production to foreign markets, high-tech manufactured goods do represent more than $80 \%$ total exports. However, a vast number of these exports are essentially produced in maquiladoras that locally assemble imported inputs with scant use of domestic intermediate products or raw materials [...] in reality, they are high-tech exports produced through rather simple assembly process that neither rely on local R\&D capacities nor have significant backward or forward linkages with domestic suppliers" (Shapiro \& Moreno-Brid, 2014, p. 193).

It seems that the governments in Latin America equated export promotion with trade liberalisation and deregulation, and their industrial policies were abandoned and their fiscal policies to promote competitiveness of selected industries were dropped. The liberalisation and open-market policies which they adopted in the 1990s were supposed to align domestic prices with international prices. This was completely the opposite of what Amsden found in her earlier study of industrial policy in South Korea (Amsden, 1989) where, in the early phase of industrialisation, the prime issue was not to 'get the price right', but to deliberately 'get the price wrong' (Amsden, 2009b).

In recent years, Latin America has improved its terms of trade and experienced a commodity export boom, which has been associated with rising imports from China but it is difficult to predict how long this will continue.

When President Lula came to power in the 1990s, Brazil adopted a long-term developmental policy to promote specific industries. With the help of its development bank (BNDES), the government provided a massive amount of finance to promote a few selected industries in the country. 
As a result, a number of Brazilian companies emerged in the 2000s as internationally competitive. For example, Petrobras emerged as a leading company within the oil and petrochemical sector, not only in Brazil but also internationally, an achievement which was made possible due to massive state support. In contrast to this, Mexico's government decided to scale down the role of the development bank in assisting and financially supporting other key domestic industries. For example, the investment potential of Pemex was severely affected due to this government decision; similarly government policy measures were taken to withdraw the support previously extended to Nafinsa and Bancomex (Shapiro \& Moreno-Brid, 2014).

The economic crisis in the developing countries in the 1980s and 1990s provided an opportunity for international financial institutions to impose 'Structural Adjustment Programmes' in the name of aid, which has since proved disastrous(Siddiqui, 2013). To cite but one example, Stiglitz found that the market liberalisation process led to foreign investors increasing their control over African resources rather than assisting them towards long-term independent development. Moreover, these policies brought further cuts in public spending in the health and education sectors(Siddiqui, $2014 b$ ), leading to further deterioration in the availability of these vital services which has impacted most negatively on the poor in the developing countries (Stiglitz, 2006).

The question arises, then, as to why the state is once again playing a leading role in South Africa's power sector, and why a similar situation can be found in some Latin American countries. The experience of South Africa's power sector represents an interesting case in which the 'standard model' of competition and privatisation was seriously considered due to pressure from the World Bank but was soon rejected.

Eskom, the South African electricity supply company, remains state owned: "Eskom has led an impressive national electrification drive. The proportion of households with access to electricity has risen from below $49 \%$ in 1993 to nearly $70 \%$ in 2003 . In the years 1994-2002, 3.8 million new households received electricity [...] Eskom was and continues to be a relatively well functioning public utility. Unlike many other developing countries, which suffer from serious operational inefficiencies, Eskom delivers reasonably reliable and quality power at low prices and it is financially viable" (Eberhard, 2005, pp. 5309-5310).

The electrification programme in South Africa represents a remarkable achievement perhaps without any international precedent, with access to electricity doubling from $33 \%$ to $66 \%$ of the population in the short period of time from the end of the 1990s to the early 2000s. Facing this challenge was necessary in order to overcome the legacy of the inequalities of apart- 
heid. The South African experience demonstrated that it is possible to make substantial progress in widening access to electricity services for the poorer sections of society who historically have been underprivileged. Although this was achieved by a state-owned enterprise, it was made possible due to technically competent and financially sound and most of all, the state's willingness to support it throughout.

This is particularly important in the countries where industrialisation historically began much later than in West European countries. When there is a need to undo historical legacies and backwardness, the state's role can be quite important. The experience of neoliberal reforms in Russia in the early 1990s highlights the dangers of ignoring the issue of governance and of giving greater powers to foreign investors. It is useful to quote Wade here: "Low private saving, dependence on primary product exports, declining prices of exports in relation to imports, small internal markets, limited skills, few entrepreneurs adept at large-scale organisation, and pervasive under employment - required an even bigger role for the state then in the more developed countries" (Wade, 2004, p. 8). In fact, there has been a long history of state intervention to promote innovation and disseminate new technologies, primarily to negate market failure when a lack of incentives for generating new technologies may lead markets to underinvest and they prove incapable of taking the lead in the R\&D of technologies.

In the Indian context, it is relevant to cite here the earlier debate between Amartya Sen and Jagdish Bhagwati (Ruparelia, et al. 2011). Sen (1999) argues in favour of state intervention in the areas such as education and health, claiming that government measures should be a starting point for tackling mass poverty and the other ills that beset India. Bhagwati, however, prefers rapid growth, and assumes that the wealth generated will presumably be utilised later to solve deprivation of various kinds including poverty (Bhagwati, 1982). Sen emphasises the importance of both state and market forces as agents of development, and advocates strong intervention by means of social welfare schemes (Sen, 1999). He believes that food, employment, health and education should be provided through government schemes entailing active state involvement, whereas Bhagwati prefers direct cash transfer to the poor who can choose private or public providers for the services they require. The important issue is that of ecological sustainability. Sen often acknowledges the need to bring environmental regulation into the equation, while Bhagwati largely ignores it. For neoclassical economists, growth is the first priority and they are not concerned about increasing inequality. 
For example, the past two decades of higher growth in India were characterised by a net decline in employment in most sectors. Some $93 \%$ of India's labour force continues to work in the informal economy without a living wage or any of the benefits or security of formal employment. While the Indian labour force has increased by 100-125 million, employment in the formal economy has grown from a meagre 26.7 million in 1991 to a still meagre 29 million in 2001 (Siddiqui, 2014a).

Neoliberalism promotes a market model of development. In education it has already brought about state withdrawal from its wide ranging responsibilities (Siddiqui, 2014b). To follow a liberalisation policy in the agricultural sector in a country with a large population like India could prove catastrophic. For instance, it could lead to land-use shifts from cultivation of grain for domestic consumption to a preference for export crops. As a result, such development could undermine domestic food security (Siddiqui, 1999). Sharp fluctuations such as a rise in prices could hurt consumers, while a sharp fall would undermine farmers' incentives to invest in the land and thereby contribute further to slowing down overall economic development (Siddiqui, 2014a).

In fact, neoliberal reforms in developing countries in recent years have weakened the state regulation of the economy and also created the conditions to promote and expand the role of private enterprises and markets (Siddiqui, 2012b). At present, with the increased process of globalisation and integration into global markets, the governments in developing countries are seen reducing taxes and government spending, selling off public companies and minimising the role of the state in economic affairs to foster more individual initiative and business opportunities(Siddiqui, 2012b).

The international financial capital of the $21^{\text {st }}$ century seems to be different in a number of such ways from the past. First, it determines the possibility of Keynesian demand management, which required state intervention to boost levels of domestic economic activity. This means using state intervention to build a productive economic base could prove controversial. Second, under capital liberalisation, the developing countries need to raise interest rates to attract capital and also foreign capital confidence becomes very important. This could lead to higher costs for borrowing, which could discourage investment and reduce aggregate demands. Higher interest rates will also increase costs for small businesses, meaning a further contraction in economic activity. On the other hand, the state will face more fiscal crises due to the increased cost of debt servicing, which cannot be met by raising taxes on the rich and corporate sector, because the open economy will be under pressure to maintain lower tax rates to attract investors and higher taxes would prove to be a disincentive. Moreover, import duties 
have to be reduced as a part of liberalised economic policy measures. All these further accentuate the fiscal crisis of the state, and as a result the government may have to cut social spending on development expenditure. These could further contract the domestic economy.

\section{State Intervention}

\section{in the East Asian Economies}

The arguments in favour of extensive state intervention have been based around the experiences of historically backward countries, their underdeveloped institutions including markets, and the absence of a strong entrepreneurial class. Malaysia's industrial policy in the recent past offers important lessons for other developing countries. The implementation of its New Economic Policy (NEP) and its successful outcomes require the state to be actively involved in the economy. For example, looking more closely at Malaysia's industrialisation, it is well established that state intervention in the last quarter of the $20^{\text {th }}$ century did help it to diversify and the country was able to build a manufacturing sector. Poverty alleviation and income redistribution was also achieved successfully by means of active state involvement as well as market coordination in an ethnically sensitive country like Malaysia (Siddiqui, 2012a).

Furthermore, Rasiah and Shari (2001) point out that from 1970 to 1990 the NEP was applied by providing strong incentives to both 'importsubstitution' and 'export-oriented' policies to develop the manufacturing sector. The adoption of NEP during the period of 1970-1990 heralded an era of rapid economic growth, job creation and a rise in incomes throughout the country. Poverty and inequality have declined and the government has been able to address the historical legacy of the ethnic divide between communities which arose largely from the colonial policies of the past. Unemployment was reduced from $8 \%$ in 1970 to $2.6 \%$ by 1996 (Siddiqui, 2012a; Rasiah \& Shari, 2001).

There seems to be no doubt that Malaysia's growth and industrialisation strategy throughout the NEP period relied on state intervention, with a coordinated role for both the state and the market. In fact, the poverty reduction measures were launched under the close supervision of the state and the outcome was remarkable. The poverty level was decreased from $49.3 \%$ of households in 1970 to $16.7 \%$ in 1990 (Siddiqui, 2012a).

Rasiah and Shari's (2001) study on the issue of state intervention concludes: "The experience of Malaysia demonstrates the need to formulate effective industrial policies, taking cognisance of the market and the institu- 
tions necessary to ensure effective coordination between firms, factor markets and product markets. Through preferential policies, the state expanded Bumiputera employment in public services and stimulated their greater participation in manufacturing, thereby succeeding in its efforts to restructure the occupational identification of ethnicity, which was complemented by land schemes and the distribution of shares among poor Bumiputera households" (Rasiah \& Shari, 2001, p. 75).

China's changes in policies in the 1978 began in the agricultural sector by giving more production (Siddiqui, 2009) and sales responsibilities to households rather than village communes, which ultimately increased the output and local participation at village levels, perhaps also allowing some wider participation in decision making. The Chinese government played the key role in all these initiatives, by changing the economic direction of the country in 1978. Later, a more active role in technological upgrading and innovation enhanced the competitiveness of Chinese industries (Siddiqui 2009).

Regarding the question of the export success of East Asian countries, Amsden (2009a) claims it is irrelevant to argue against the 'import substitution' and 'export promotion' policies. In her study of the East Asian countries, she finds that both policies complemented each other. She further argues that "only one simple story tends to repeat itself: behind the rise of every export was an earlier import substitution investment policy" (Amsden, 2009a). It was argued that free-market and laissez-faire policies enabled East Asian countries to achieve spectacular rates of export growth as a result of the competitiveness enforced by their exposure to the international market (World Bank, 1993). However, contrary to such claims, it is now known that these economies were highly protectionist, dirigiste regimes (Chang, 2002; Amsden, 1989).

The East Asian economies experienced higher rates of growth for more than four decades until 1997 and became developmental success stories thanks to state intervention policies. These countries used government policy to guide the markets.

There has been an acceleration of growth rates in East Asian countries such as South Korea, Singapore, Taiwan and Malaysia in the 1970s and 1980s, namely in countries who hardly followed neoliberal prescriptions (Siddiqui, 2010b).These countries have achieved high rates of economic growth via strong state direction in economic policy matters (Wade, 2004). Moreover, the successful emerging economy also needs to be independent, dealing with their domestic classes whilst also controlling non-state agents. The state also uses power and resources to implement interventionist policies, which runs contrary to the prescription of international financial agen- 
cies. Unsuccessful emerging economies pursue interventionist policies but end up failing because they are pressurised by special domestic and international interest groups, and obviously lack relative autonomy. For example, the state played a key role in the development and performance of the Japanese and Korean steel industries and also in building other modern industries such as Korean shipbuilding, cars and electronics; Indian agriculture in the 1960s (Siddiqui, 1999), and its IT sector in the 1990s; Argentina's finance sector; South Africa's mining and power sectors (Siddiqui, 2014a). All these were successfully achieved with state assistance (Fine et al., 2013; Amsden, 1989).

For more than two decades, economic policies, particularly those in Latin American and African countries, have been dominated by marketoriented policies. The imposition of neoliberal policies across the developing countries and in the economics profession via multilateral institutions such as the World Bank, the IMF and the WTO together with the Western governments could be clearly seen(Siddiqui, 1994b). In fact, both the debt crisis in the 1980s and the East Asian financial crisis in 1997 served to strengthen the grip of neoliberalism, with policies being revisited rather than dropped. But the IMF's credibility as an institution weakened in developing countries (Siddiqui, 2014b; Stiglitz, 2006).

\section{Conclusions}

This study has argued that economic governance is crucial for development, since it is associated with the ability of actors to participate in decision-making processes, which have an impact on economic growth, job creation, income, investment and the environment within a country. With the adoption of neoliberal policies, the corporate and financial sector and bureaucrats have acquired increased power in developing countries. It also means that national sovereignty itself is being threatened in the name of socalled growth and market efficiency. Neoliberal reforms in developing countries have led to a reduction in the role of the state whilst market forces have been assigned a correspondingly greater role. Neoliberalism also promoted the interests of the corporate-financial capital on the grounds that what is good for them is good for the nation. Similarly they failed to predict and analyse the 2008 financial crisis, and also provided very little theoretical justification for the interventionist policy measures which were applied at the beginning of the crisis. 
More than three decades of experience have shown that far from promoting economic growth, neoliberalism has not succeeded in reducing the levels of poverty, particularly in Africa and Latin America, where such policies were launched more than two decades ago. For example, the average annual rise in per capita income in the developing countries has slowed down from 3\% during the interventionist period of 1960-1980 to 1.5\% during the following two decades 1980-2000. Moreover, the most disturbing fact is that in the poorest developing countries (i.e. those with per capita GDP of US\$ 375-1121), this declined from 1.9\% in the first period to just $0.5 \%$ during the second period of the neoliberal reforms(Chang, 2002).

We should perhaps then make a concerted effort to dispel the myth that market competition is overwhelmingly a source of innovation and competitive advantage. The truth is that the government plays a huge role as the ultimate risk taker, financier and social coordinator, both between firms and workers, and between firms and the state. The state should engage more in economic developmental and policy matters and that are adjustment is required, shifting away from high levels of reliance on the financial sector and market forces towards more sustainable productive activities (Wade, 2009). Industrial policy could broadly include such aspects as support for 'infant industries', trade policies, and policies affecting foreign capital and investment. This means establishing guidelines covering the operation of the market and setting the boundaries between what should be governed by the market and what should not (Wade, 2009; Narcis \& Stiglitz, 2009).

In the past the state had a good record of stimulating innovation-led growth, not only by mitigating private sector risks but also taking risks that the private sector would not take. For example, the development of aviation, nuclear energy, computers, biotechnology, and solar energy were all successfully achieved by means of state support. Developing countries require an industrial policy in which the government takes a clear role in leading innovation in renewable energy techniques, public transport, health and education.

The question of the distribution of surplus and the issue of social justice are not recognised in neoliberal analysis as economic issues requiring important consideration.

For neoclassical economists it appears that capital formation as an efficient allocation of resources is not viewed as a crucial factor of development. Once instructional arrangements are in place to generate efficient allocation of resources then investment can take care of itself. Their models totally ignore the historical legacies of underdevelopment, pretending that the past was free from difficulties and trying to blame the current problems on the developing countries themselves. 
There are a number of reasons why the neoliberal model is not sustainable. In most of the developing countries, the income distribution was very unequal; therefore, the domestic markets remained highly unequal and were unable to absorb the manufactured goods produced (Siddiqui, 2010a).

The crisis which the developing countries have experienced for more than two decades shows how futile it is to assume that this could be resolved once the primacy of the market had been restored, and that the economy will naturally develop as long as the state does not interfere with its functioning. These claims are false with little if any support from historical precedents. The state should act in the interests of the majority in order to promote overall human development.

\section{References}

Amsden, A. (2009a). The wild ones: industrial policies in the developing world. In: S. Narcis, J. Stiglitz (Eds.). The Washington Consensus Reconsidered. London: Oxford University Press.

Amsden, A. (2009b). The Rise of "The Rest": Challenges to the West from LateIndustrialising Countries. London: Oxford University Press.

Amsden, A. (1989). Asia's Next Giant: South Korea and Late Industrialisation. Oxford: Oxford University Press.

Bhagwati, J. N. (1982). Directly Unproductive Profit Seeking (DUP) Activities. Journal of Political Economy, 90(5).

Chang, Ha-Joon (2007). Bad Samaritans. London: RH Business Books.

Chang, Ha-Joon (2002). Breaking the Mould: an institutionalist political economy alternative to the neoliberal theory of market and state. Cambridge Journal of Economics, 26(5). doi:10.1093/cje/26.5.539.

Cowling, K., \& Tomlinson, P. R. (2011). Post the 'Washington Consensus': economic governance and the industrial strategies of the $21^{\text {st }}$ century. Cambridge Journal of Economics, 35(5). doi:10.1093/cje/ber003.

Eberhard, A. (2005). From State to Market and Back Again - South Africa's Power Sector Reforms. Economic and Political Weekly, $10^{\text {th }}$ December.

Fine, Ben, Saraswati, J., \& Tavasci, D. (Eds.) (2003). Beyond the Developmental State: Industrial Policy into the $21^{s t}$ Century. London: Pluto.

Friedman, T. (1999). The Lexus and the Olive Tree. New York: Farrar, Strauss.

Girdner, E. J., \& Siddiqui, K. (2008). Neoliberal Globalization, Poverty Creation and Environmental Degradation in Developing Countries. International Journal of Environment and Development, 5(1).

Goldsmith, A. A. (1995). The State, the Market and Economic Development: A Second Look at Adam Smith in Theory and Practice. Development and Change. 26(4). doi: 10.1111/j.1467-7660.1995.tb00568.x.

Harcourt, W. (2014). The Future of Capitalism - a consideration of alternatives. Cambridge Journal of Economics. 38(6), doi:10.1093/cje/bet048. 
Hirschman, A. (1982). Shifting Involvement, Princeton, NJ: Princeton University Press.

Kitson, M. (2005). The American Economic Model and the European Economic Policy. Regional Studies, 39(7). doi:10.1080/00343400500290075.

Krueger, A. (1974). The Political Economy of the Rent Seeking Society, American Economic Review, 64.

List, F. (1966). The National System of Political Economy. New York: Augustus Kelley.

Little, I. (1982). Economic Development: Theory Policy and International Relations. New York: Basic Books.

Narcis, S., \& Stiglitz J. (Eds.) (2009). The Washington Consensus Reconsidered. Oxford: Oxford University Press.

Perelman, M. (2011). The Invisible Handcuffs: How Market Tyranny Stifles the Economy by Stunting Workers. New York: Monthly Press.

Polanyi, K. (1957). The Great Transformation, Boston. MA: Beacon Press.

Rasiah, R., \& Shari, I. (2001). Market, Government and Malaysia's New Economic Policy. Cambridge Journal of Economics, 25(1). doi:10.1093/cje/25.1.57.

Ruparelia, S., Reddy, S., \& Corbridge, S. (Eds.) (2011). Understanding India's New Political Economy. London: Routledge.

Shapiro, H., \& Moreno-Brid, J.C. (2014). Alice Amsden's Impact on Latin America. Brazilian Journal of Political Economy, 34(2).

Sen, A. (1999). Development as Freedom. London: Oxford University Press.

Siddiqui, K. (2014a). Growth and Crisis in India's Political Economy from 1991 to 2013. International Journal of Social and Economic Research, 4(2). DOI:10.5958/2249-6270.2014.00487.5.

Siddiqui, K. (2014b). Higher Education in the Era of Globalisation, International Journal of Humanities and Social Science, 3(2).

Siddiqui, K. (2013). A Review of Pakistan's Political Economy. Asian Profile. 41(1).

Siddiqui, K. (2012a). Malaysia's Socio-Economic Transformation in Historical Perspective. International Journal of Business and General Management, 1(2).

Siddiqui, K. (2012b). Developing Countries Experience with Neoliberalism and Globalisation. Research in Applied Economics, 4(4). DOI:http://dx.doi.org/ 10.5296/rae.v4i4.2878.

Siddiqui, K. (2010a). Globalisation and Neo-liberal Economic Reforms in India: A Critical Review. In: S. K. Pramanick, R. Ganguly (Eds.). Globalization in India: New Frontiers and Emerging Challenges. New Delhi: Prentice Hall.

Siddiqui, K. (2010b). The Political Economy of Development in Singapore. Research in Applied Economics, 2(2). DOI: http://dx.doi.org/10.5296/rae.v2i2.

Siddiqui, K. (2009). The Political Economy of Growth in China and India. Journal of Asian Public Policy, 1(2). DOI: 10.1080/17516230902734528.

Siddiqui, K. (1999). New Technology and Process of Differentiation: Two Sugarcane Cultivating Villages in UP, India. Economic and Political Weekly, 34(52).

Siddiqui, K. (1994a). World Bank: 50 Years of neo-liberalism and Diktat. The Nation, 5th \& 6th September. 
Siddiqui, K. (1994b). The Economic Philosophy of Neo-liberalism. The Nation, 20th September

Smith, A. (1937). An Enquiry into the Nature and Origin of the Wealth of Nations. New York: Modern Library.

Smith, A. (1976). The Theory of Moral Sentiments. Oxford: Claredon.

Stiglitz, J. (2006). Making Globalisation Work. London, Penguin Books.

Wade, R. (2009). From Global Imbalances to Global Reorganisations. Cambridge Journal of Economics, 33.

Wade, R. (2004). Governing the Market. New Jersey: Princeton University Press.

Williamson, J. (2003). The Meaning of the Washington Consensus. World Development, 21(8).

World Bank (1993). The East Asian Miracle: Economic Growth and Public Policy. New York: Oxford University Press. 